\title{
Evaluation of (cytotoxicity and angiogenesis) of Zinc oxide nanoparticles Synthesized by aqueous extract of Origanum majorana
}

\author{
Somayeh Khaleghi ${ }^{1}$ (D), Jina Khayat Zadeh ${ }^{2}$ (D), Ali Neamati ${ }^{3}$ \\ ${ }^{1}$ Department of Biology, Mashhad Branch, Islamic Azad University, Mashhad, Iran \\ 2 Corresponding author; Department of Biology, Mashhad Branch, Islamic Azad University, Mashhad, Iran \\ Tel: $+985138435050 \quad$ FAX: $+985138435050 \quad$ Email: j_kh329@yahoo.com \\ ${ }^{3}$ Department of Biology, Mashhad Branch, Islamic Azad University, Mashhad, Iran
}

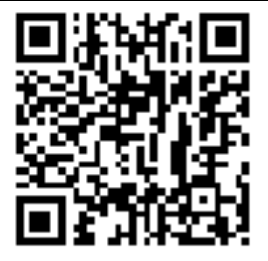

Citation Khaleghi S, Khayat Zadeh J, Neamati A. [Evaluation of (cytotoxicity and angiogenesis) of Zinc oxide nanoparticles Synthesized by aqueous extract of Origanum majorana]. J Birjand Univ Med Sci. 2020; 27(1): 56-67. [Persian]

DOI http://doi.org/10.32592/JBirjandUnivMedSci.2020.27.1.104

Received: March 2, 2019

Accepted: August 21, 2019

\begin{abstract}
Background and Aim: Zinc oxide nanoparticle ( $\mathrm{ZnO}$ NPs), Due to its unique properties, such as its anti-cancer and antioxidant properties, it has attracted researchers attention. In the present study, the cytotoxic and anti-angiogenic properties of zinc oxide nanoparticles prepared with the green method from extract Origanum Majorana were investigated.

Materials and Methods: Cytotoxic effects of zinc oxide nanoparticles, By MTT assay on cells of HUVEC ،MDA-MB-231 and Hep-

G2 was examined. In order to evaluate the anti-angiogenic effects in an in vivo model, 48 fertile eggs with Ross breed randomly divided into 6 groups Consist of: 4 treatment groups with different concentrations of $(125,250,500$ and $1000 \mu \mathrm{g} / \mathrm{ml})$, control and sham groups. After 12 days of incubation, the number and the length of the vessels of the chorioallantoic membrane of chick embryos were assessed. Eventually, data were analyzed using Image J and SPSS software (version 16) and one-way ANOVA and post hoc LSD statistical tests at the significant level $(\mathrm{P}<0.05)$.

Results: The results showed that $\mathrm{ZnO}$ nanoparticles made the concentration-dependent cytotoxic effects with the amount IC50 values of 60,15 and $80 \mu \mathrm{g} / \mathrm{ml}$. The number and length of chorioallantoic membrane vessels and by chick embryos weight and height in treated groups with different concentrations of nanoparticles significantly decreased compared to the control group $(\mathrm{p}<0.05)$.

Conclusion: The Zinc oxide nanoparticles produced by the green method from the extract of Marjoram probably with more severe cytotoxic properties for cancerous cells compared to healthy cells and it can also have anti-angiogenic potential.
\end{abstract}

Key Words: Angiogenesis; Chorioallantoic Membrane; Cytotoxicity; Origanum Majorana; ZnO-NPs 


\title{
ارزيابى سميّت و آذزيوزنز نانو ذرّه اكسيل روى سنتزشهه با عصاره آبى كياه مرزنجوش (Origanum majorana)
}

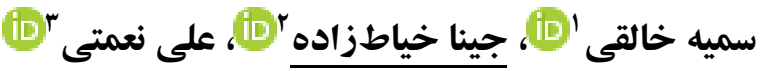

جككيله

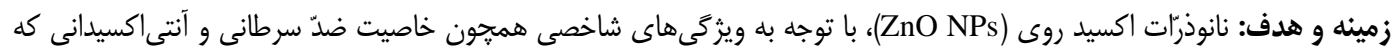

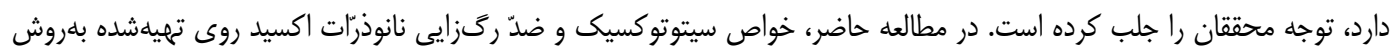

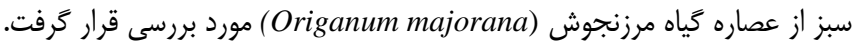

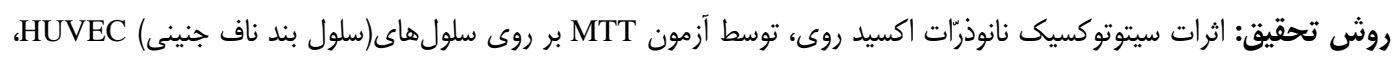

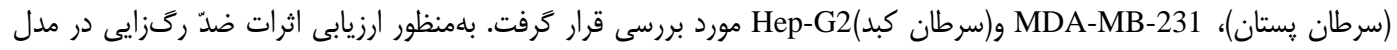
In vivo

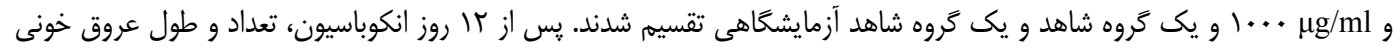

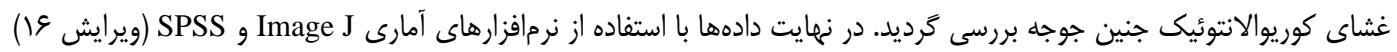

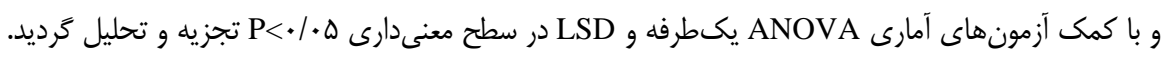

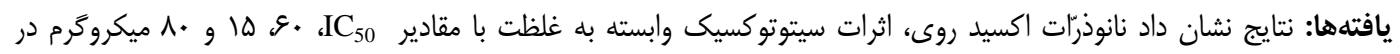

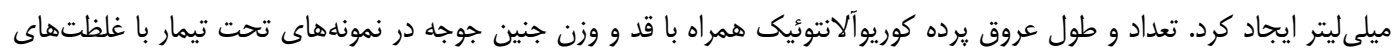

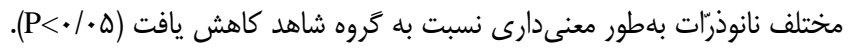

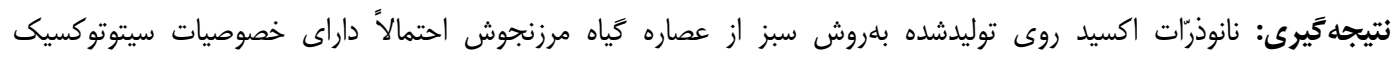

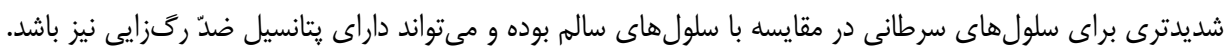

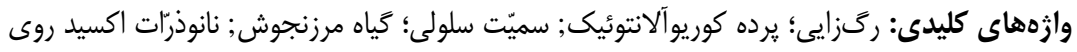

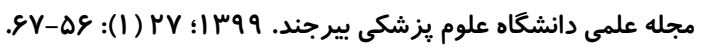

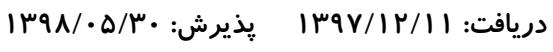

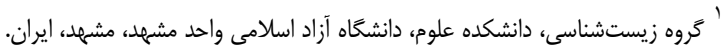

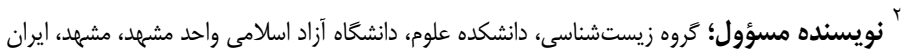

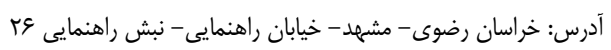

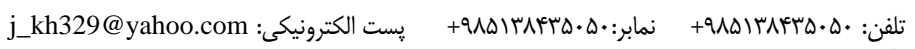

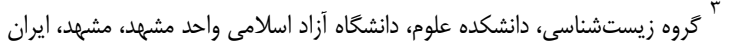


يزشكى، استفاده از نانوذرّات فلزى از جمله نانوذرّات مقاله

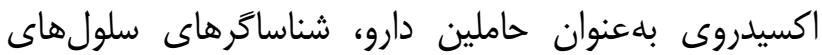

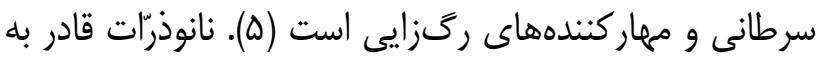

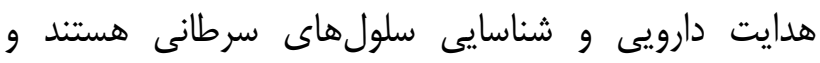

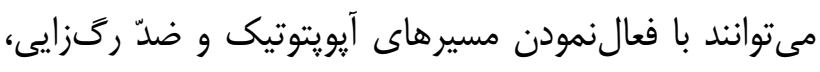

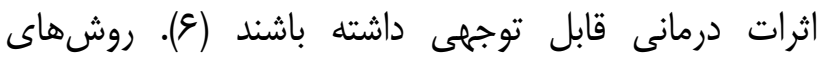

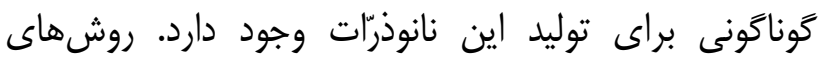

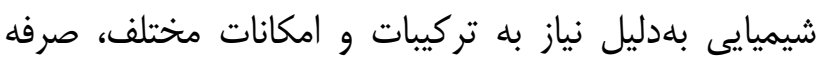

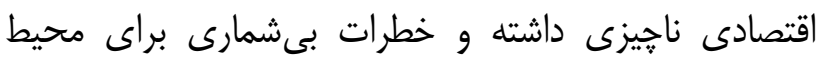

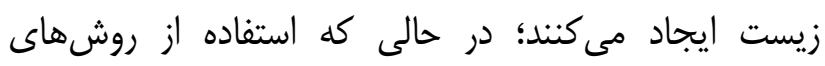

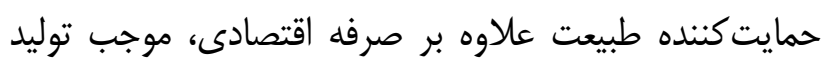

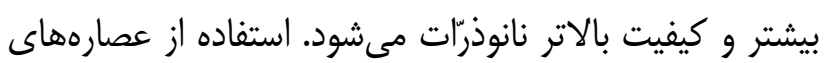

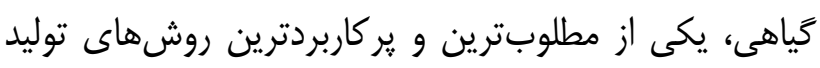

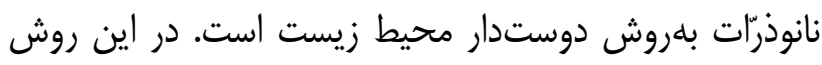

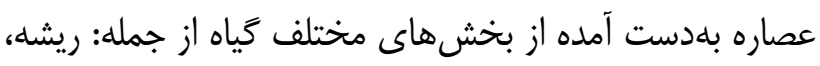

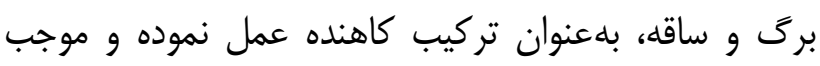

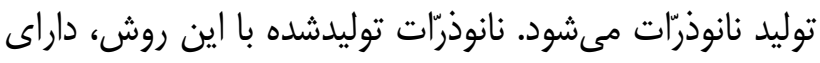

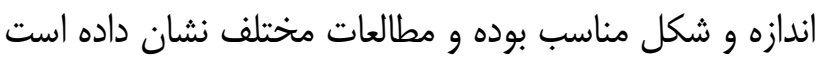

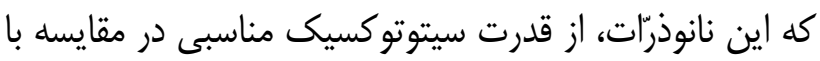
ساير نانوذرّات توليدشده به روشهاى شيميايى برخوردار

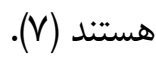

استفاده از فلز روى براى توليد نانوذرّات اكسيدروى

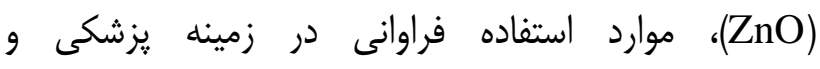

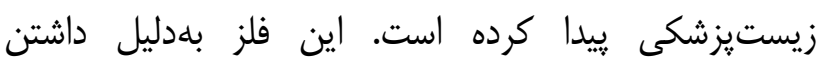

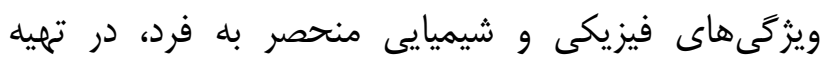

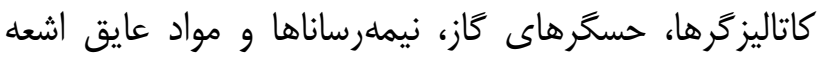

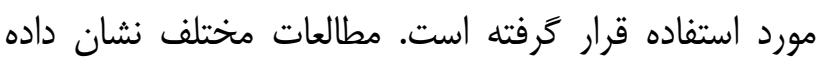

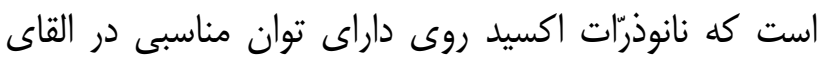

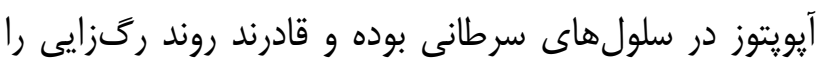

در بافتهاى سرطانى سركوب نمايند (1).

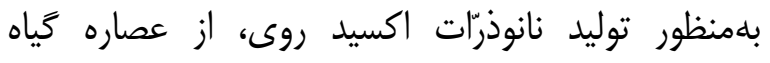
مرزنجوش (Origanum majorana) استفاده شد. شاه سرطان دومين عامل مركى و مير در كشورهاى در حال توسعه و اولين عامل در كشورهاى توسعه يافته است. على دردي رغهم كسترش روشهاى متنوع درمانى از جمله شيمىدرمانى،

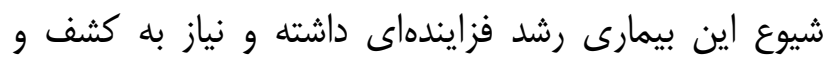

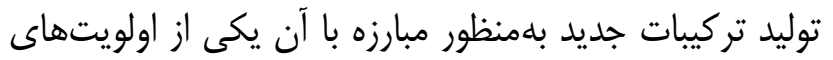
مهم جهانى محسوب مىشود (().

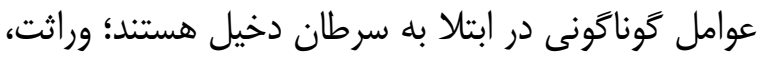

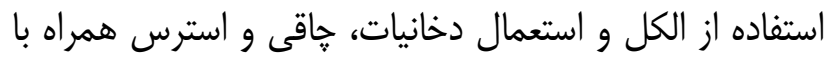

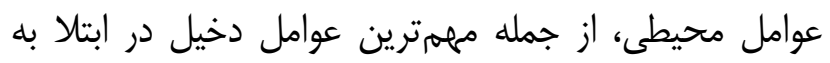

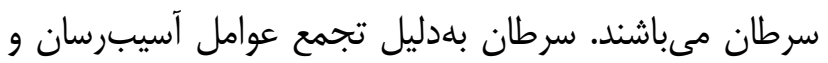

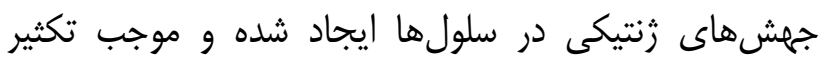

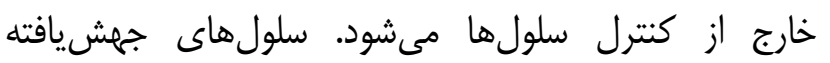
بهدليل آسيبهاى وارد شده تكثير مى شوند؛ در نتيجه اكسيثن

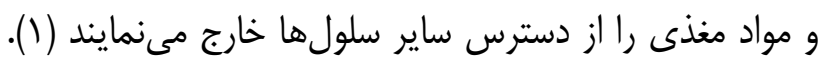

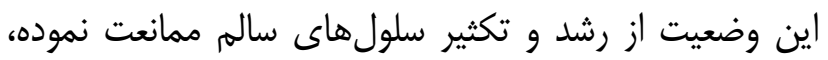
در حالى كه سلولهاى سرطانى با افزايش اندازه موجب ايجاد صدمات فيزيكى شده و يا به ساير بافتهاى بلد بلن حمانه

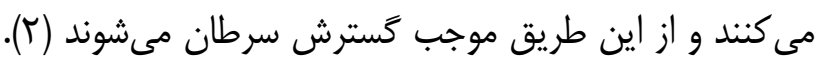

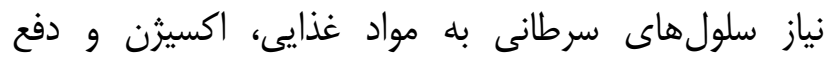

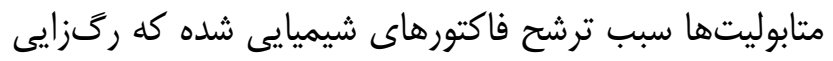

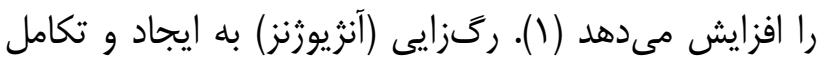

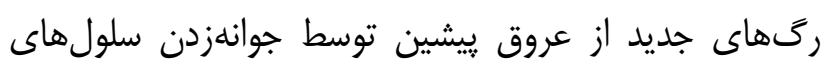

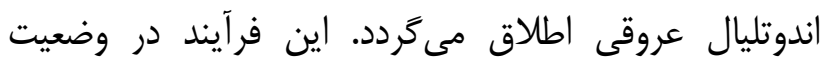

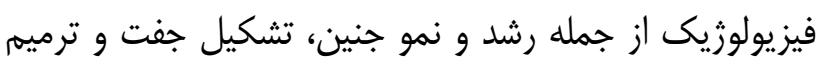

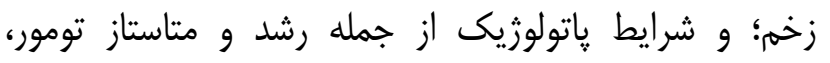

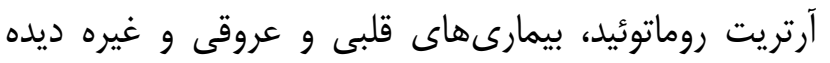

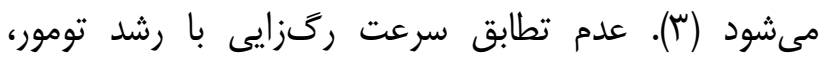

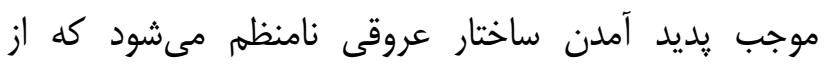

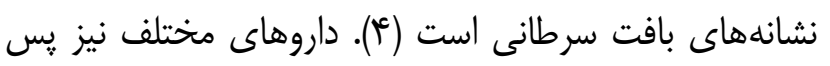

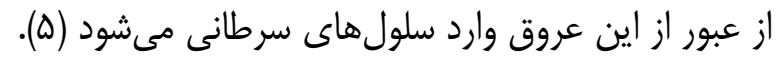

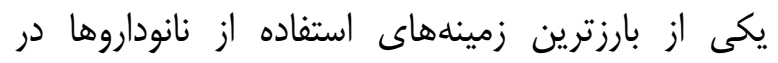


يك ساعت در دماى C C

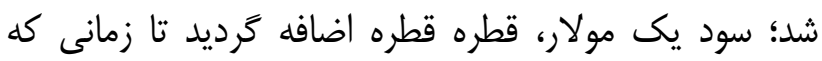
محلول به رنگ سفيد تغيير ييدا كرد. محلول حاوى نانوذرّات

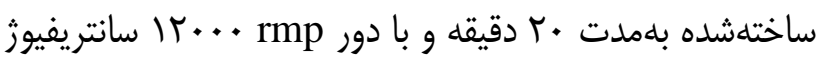

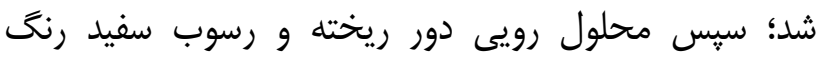

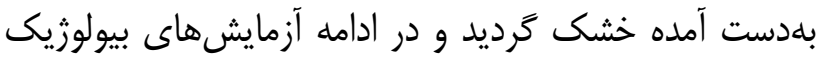

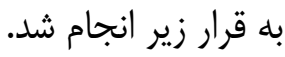

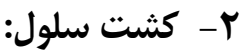

MDA- در اين مطالعه، از ردههاى سلولى سرطانى MB231 سلولى HUVEC (سلول بند ناف جنينى) استفاده شد. اين

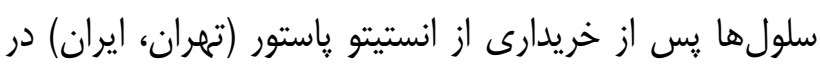

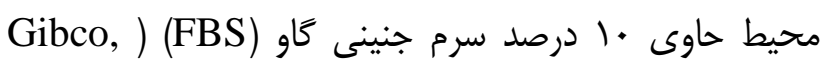
و يك درصد آنتىبيوتيك استريتومايسين و (USA

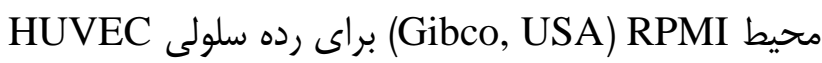
MDA- براى ردههاى سلولى براى رده سلى (Gibco, USA) DMEM و

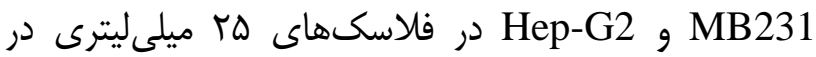

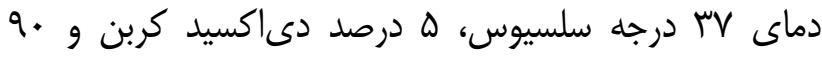
درصد رطوبت كشت داده شدند. ياساز سلولى در زمانى كه • • درصد كف فلاسكها توسط سلولها مفروش شده بود، به

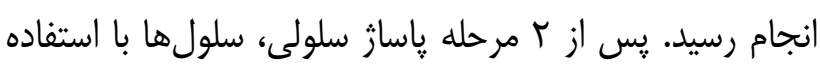

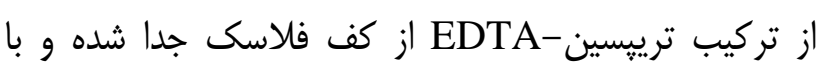

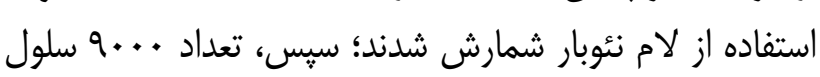

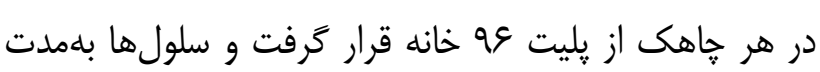

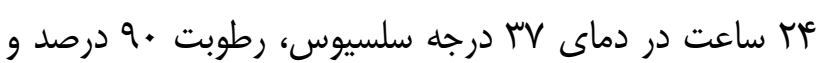
ه درصد كربن دىاكسيد انكوبه شدند (1).

س- بررسى تأثير سايتوتوكسيك نانوذرّات اكسيد روى:

روش MTT (دى متيل تيازول - r و ه دى فنيل

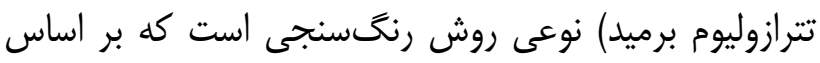

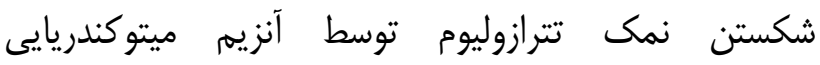

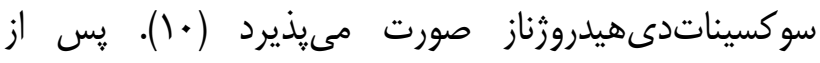

مرزنجوش (Origanum majorana) داراى تركيبات مختلفى مانند: فلاونوييدها، ترييننها و رزمارينيك اسيد است.

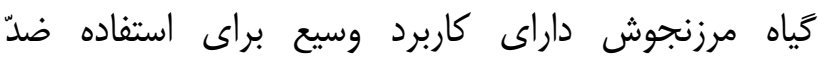
ميكروبى و آنتىاكسيدان است. در طب سنتى از إين إن خياه

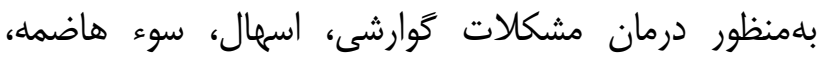

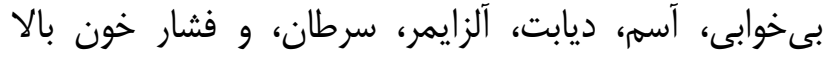

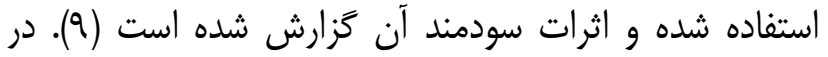

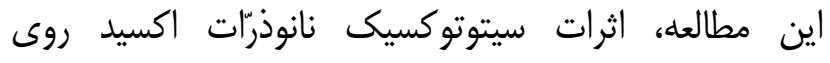
توليدشده به روش سبز با استفاده از عصاره آبى كياه

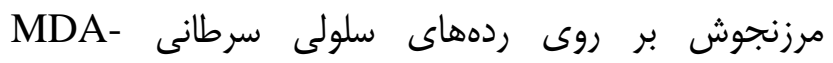
Hep-G2 و و يا سلولهاى طبيعى و HهVEC ،MB231 مورد ارزيابى قرار كرفت. همجنين اثرات اين تركيب بر سارئ

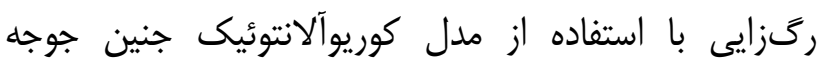
' براسى گرديد. '(CAM)

ا - بيوسنتز نانوذرّات اكسيدروى با استفاده از عصاره

\section{آبى كَياه مرزنجوش:}

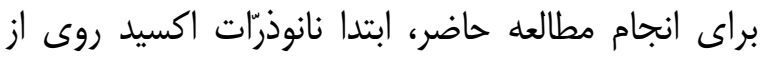

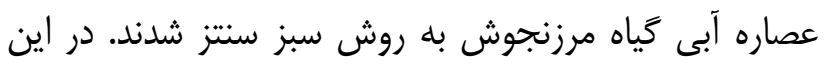

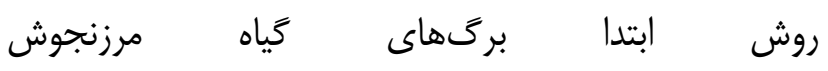
در فصل بهار از شهر مشهر (Origanum majorana)

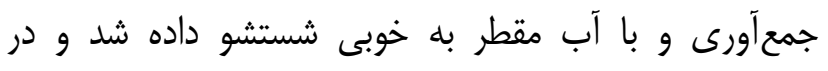

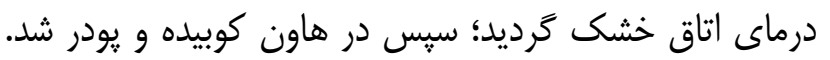

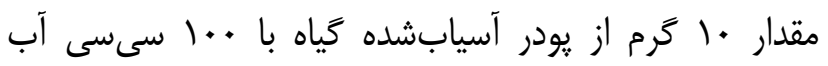
مقطر بلهدت يك ساعت در دماى • أ درجه سانتى

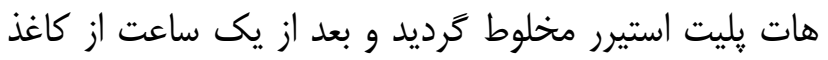
صافى وايتمن نمره يك عبور داده شد تا عصاره آبى خياه

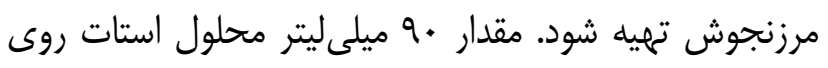

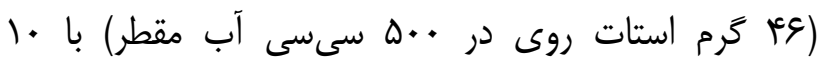

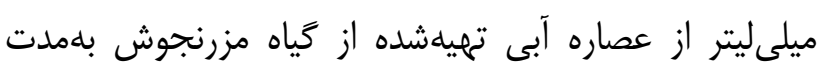

${ }^{1}$ Chorio allantoic membrane 


\section{كَروه دوم (كروه شاهد آزمايشكاهى): به نمونههاى اين}

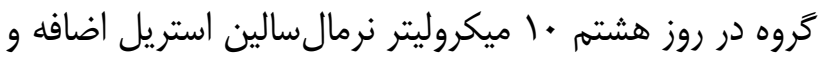

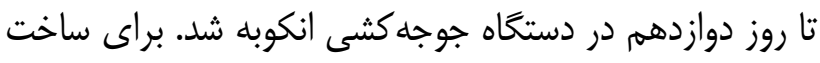

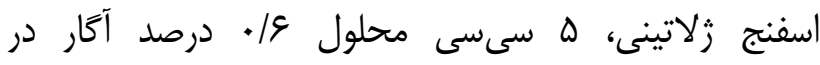

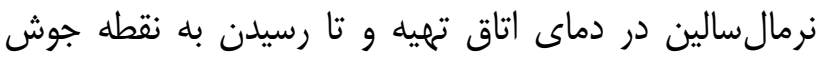

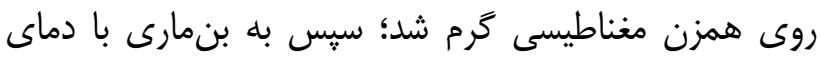

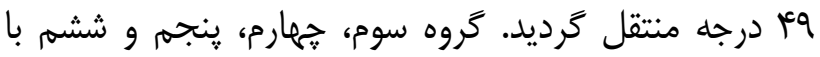

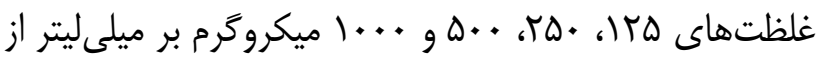

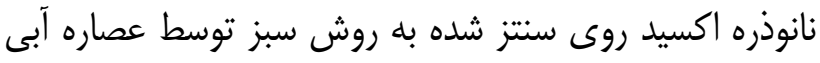

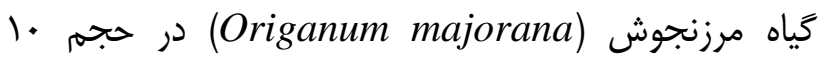

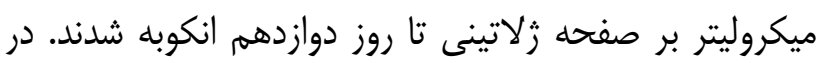

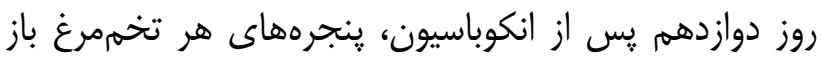

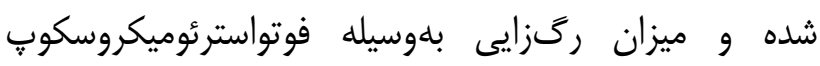
(مارى Nikon, USA) مورد بررسى قرار گرفت (سا، זוا).

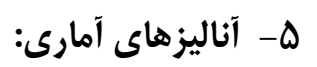

بdمن بامنور انجام تحليلهاى آمارى، از نرمافزار

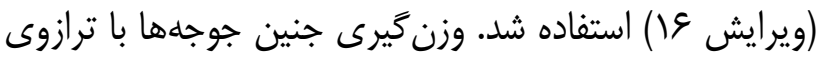

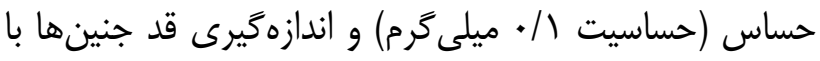
استفاده از كوليس با حساسيت • إ ميكرون به انجام رسيد. تعداد و طول انشعابات مويرگهاى خونى در سطح مقطع

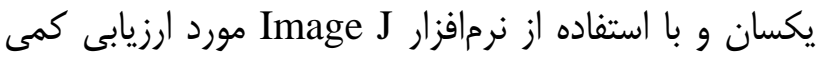

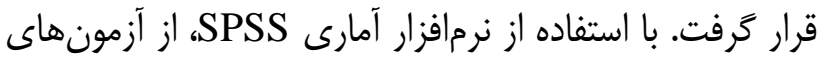

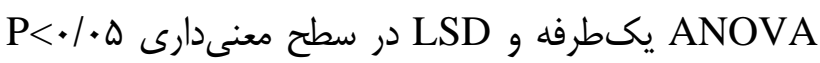

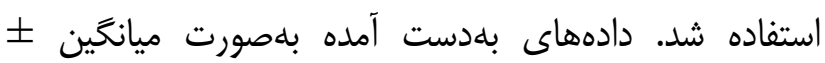
انحراف معيار ارائه گرديد. در اين مطالعه، در كليه مراحل آزمايش معيارهاى اخلاقى

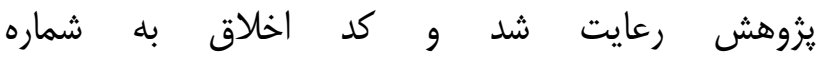
IR.IAU.MSHD.REC.1398.046 از كميته اخلاق دانشگاه آزاد اسلامى مشهر اخذ كرديد.
انكوباسيون ع M ساعته، سلولها با غلظتهاى مختلف

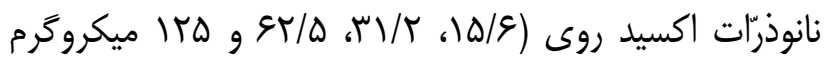
بر ميلىليتر) براى رده HUVEC و ردههاى سرطانى بلهمدت

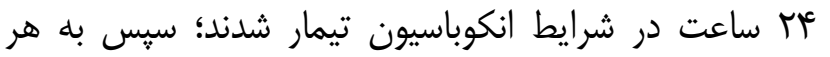

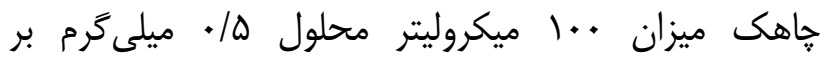

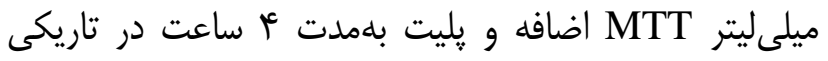

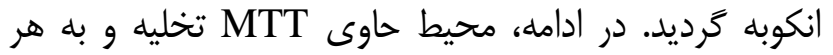

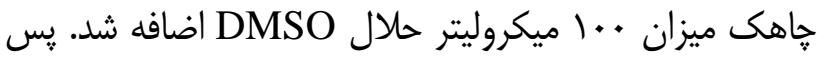

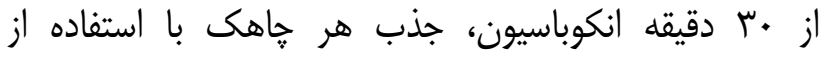

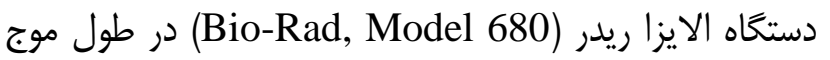

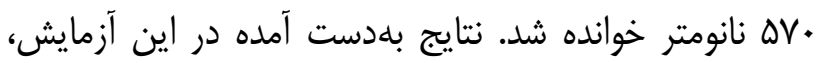

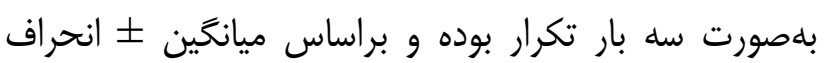

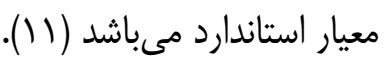

\section{F - آمادهسازى غشاى كوريوآلانتوئيك:}

اين آزمايش بلمنظظور ارزيابى اثرات ضدّ رَّزايى نانوذرّات

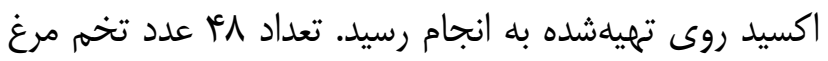
نزاد ROSS از كارخانه مرغداران توس (مشهرد، ايران) خريدارى شد؛ سيس تخم مرغها توسط الكل •V درصد تميز

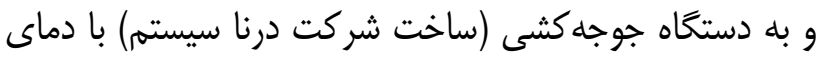
אץ درجه سانتى گراد و رطوبت سوجهاه سر يهن تخم مرغها به سمت بالا باشد- وارد شد و و كليد

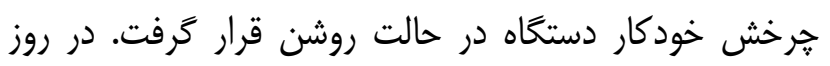

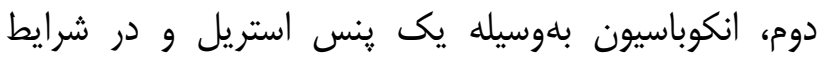

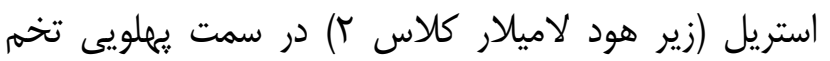

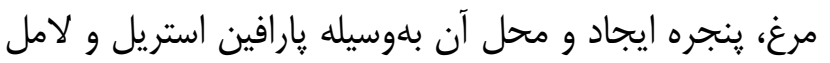

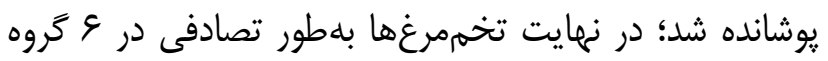
هشتتايى به شرح زير طبقهبندى شدند: كروه اول (كروه كنترل): نمونههاى مربوط به اين خروه

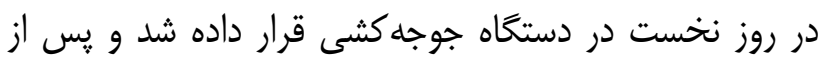

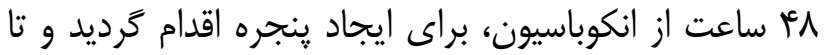
روز دوازدهم در همين وضعيت و بدون تيمار انكوبه شدند. 


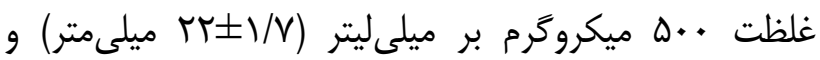
يافته ها

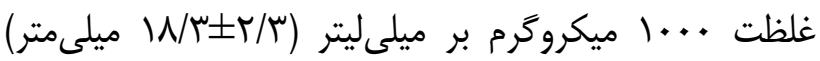

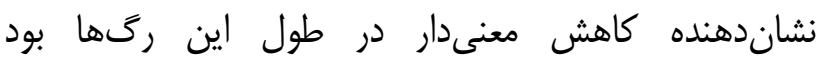
. $(\mathrm{P}<\cdot 1+\cdots)$

_ـتغيير تعداد عروق خونى بعد از تيمار با نانوذّرّات

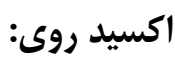

مقايسه ميانخين تعداد عروق خونى ڤرده كورئوآلانتوئيك

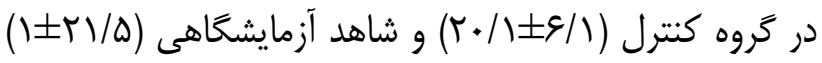
تفاوت معنىدارى را نشان نداد؛ در حالى كه مقايسه تعداد

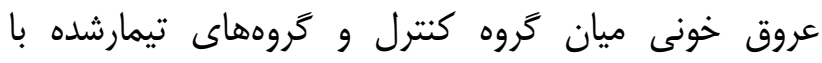

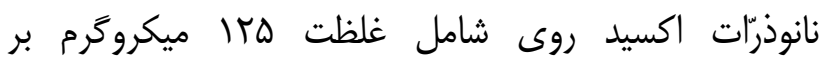

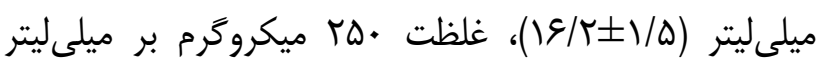
(أ) (I/

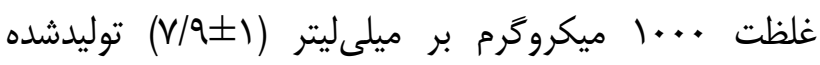

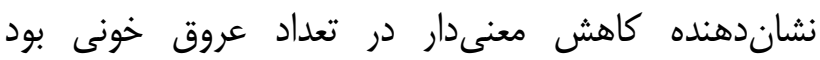
. $(\mathrm{P}<+1+\cdot 1)$

- بررسى قد جنينها بعد از تيمار با نانوذرّات اكسيد

مقايسه ميانغين قد (فاصله از فرق سر تا نشيمنگاه)

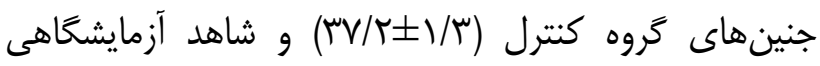
تفاوت معنى (rVI///)

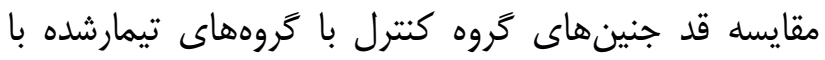
نانوذرّات اكسيد روى توليدشده از عصاره آبى كياه مرزنجوش كرون

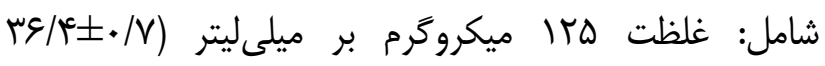

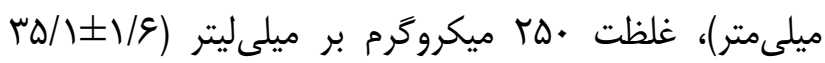

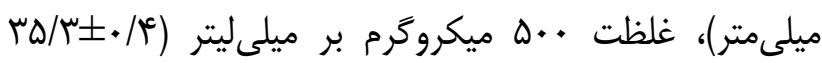

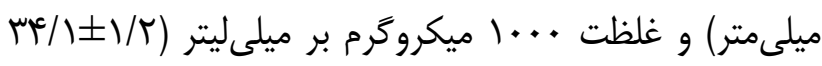

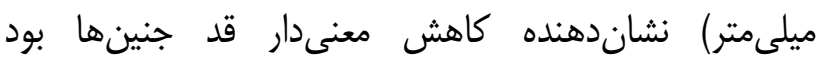
. (P<+1+. 1)

\section{ا - بررسى اثرات سايتوتوكسيك نانوذرّات اكسيد روى:}

ارزيابى اثرات نانوذرّات اكسيد روى تهيهشده باتسونا عصاره

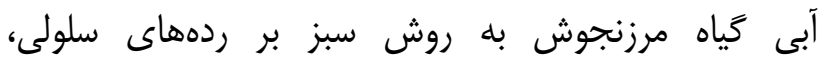

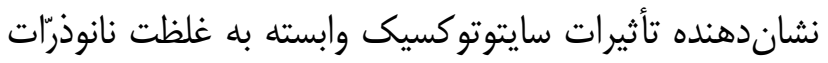

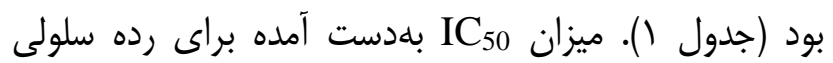
در مدت زمان ع MUVEC ميلىليتر و ميزان IC50 بلدست آمده براى ردههاى سلولى مانى

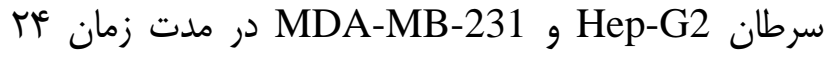

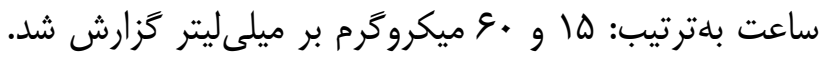

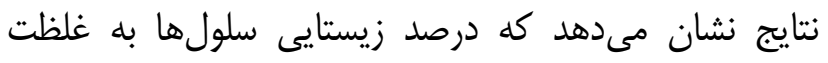
نانوذرّه بستخى دارد. در غلظت كمتر، درصد ده بقاى سلولها

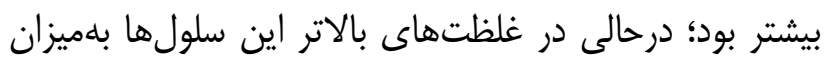
بيشترى دجار مرى و مير شدند.

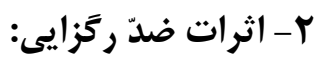

در مطالعه حاضر ارزيابى تعداد و طول رگتهاى مورئ مورد

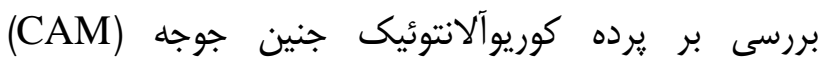

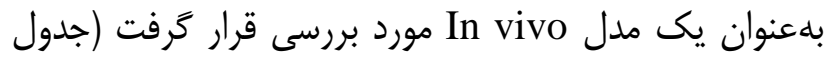

- تغيير طول عروق خونى بعد از تيمار با نانوذّرات

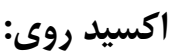

مقايسه ميانگين طول ركهاى ايجادشده بر زيرده

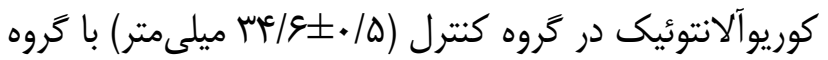

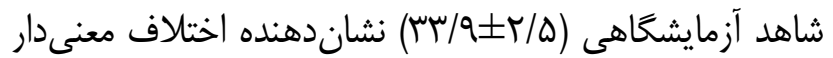

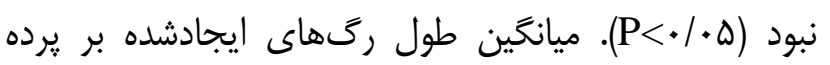

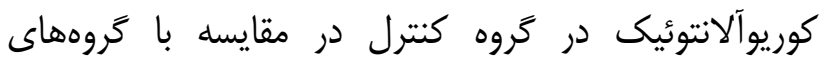
تيمارشده با غلظتهاى مختلف نانوذرّات اكسيدروى شامل:

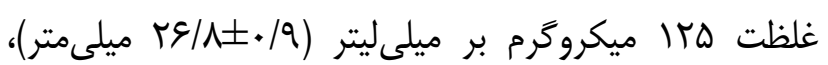

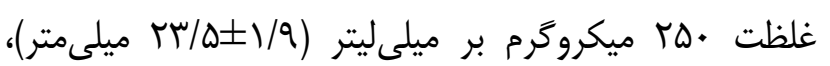


جدول ا - تعيين IC50 و مقايسه تعداد سلولى ناشى از اثر نانوذّره اكسيد روى سنتزشده از عصاره كياه

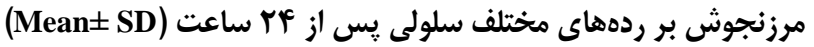

\begin{tabular}{|c|c|c|c|c|c|c|c|}
\hline \multirow{2}{*}{ سلول } & \multicolumn{7}{|c|}{ غلظت } \\
\hline & + & $10 / 9$ & TI/T & \&Y/D & Ird & P-value & IC50 \\
\hline HUVEC & $1 \cdots$ & $1 \cdots$ & $9 r / 0$ & s. & me/m & $* * * \mathrm{P}<\cdot / \cdot \cdot 1$ & $\wedge$. \\
\hline MDA-MB231 & $1 \cdots$ & $\Delta \Lambda / F$ & קع/צ & $r \Delta / \Delta$ & $1 \varepsilon /\left.\right|^{c}$ & $* * * P<\cdot / .+1$ & q. \\
\hline Hep-G2 & $1 \cdots$ & $\Lambda \bowtie / \Delta$ & $V Q / r$ & $\lceil\wedge / \varepsilon$ & $19 / r$ & $* * * \mathrm{P}<\cdot / .+1$ & 10 \\
\hline
\end{tabular}

- بررسى وزن جنينها بعد از تيمار با نانوذرّات اكسيد روى توليدشده از عصاره آبى كياه مرزنجوش شامل: غلظت

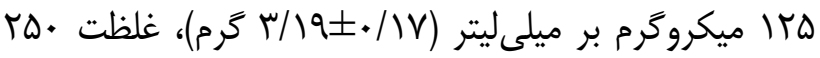

مقايسه وزن جنين جوجههاى گروه كنترل (ه+/.

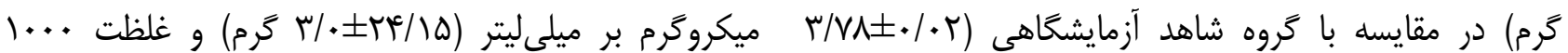

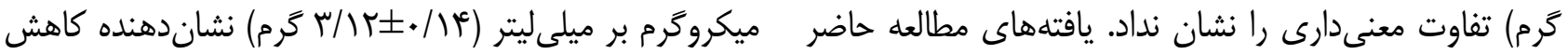

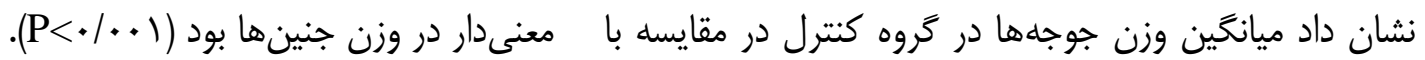

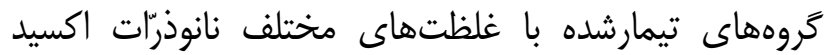

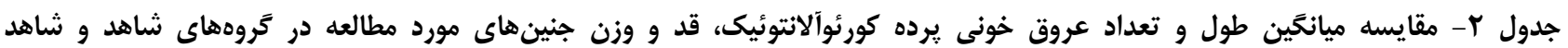

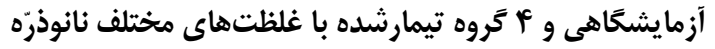

\begin{tabular}{|c|c|c|c|c|}
\hline سطح معنىدارى & انحر افمعيار & $\begin{array}{c}\text { ميانكَين } \\
(\text { Mean } \pm \text { SDD }\end{array}$ & 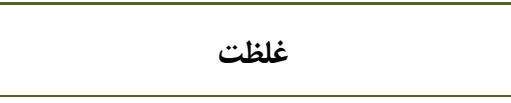 & 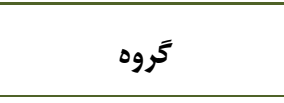 \\
\hline NS & $\cdot 10$ & 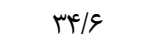 & طول عروق خونى يرده كوريوآلانتوئيك جنين جوجه & \multirow{4}{*}{ 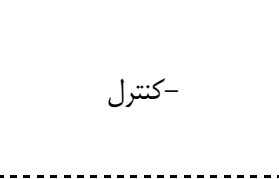 } \\
\hline NS & $1 / 1$ & $r+/ \varepsilon$ & تعداد عروق خونى يرده كوريوآلانتوئيك جنين جوجه & \\
\hline NS & $1 / r$ & rV & 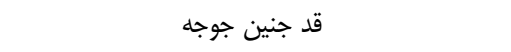 & \\
\hline NS & $\therefore 0$ & 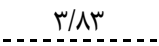 & 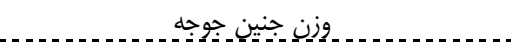 & \\
\hline NS & $r / Q$ & $r \mu / q$ & طول عروق خونى يرده كوريوآلانتوئيك جنين جوجه & \multirow{4}{*}{ شاهد آزمايشخاهى } \\
\hline NS & $1 / \Delta$ & rI & تعداد عروق خونى يرده كوريوآلانتوئيك جنين جوجه & \\
\hline NS & $\cdot / 1$ & rV & قد جد جنين جوجه & \\
\hline NS & $.1+r$ & r/v & 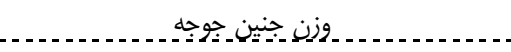 & \\
\hline$* * * \mathrm{P}<\cdot / \cdot+1$ &.$/ 9$ & re/A & طول عروق خونى يرده كوريوآلانتوئيك جنين جوجه & \multirow{4}{*}{ 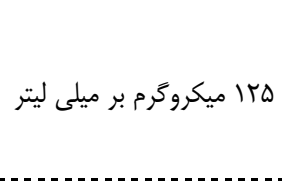 } \\
\hline$* * * \mathrm{P}<\cdot / \cdot+1$ & $1 / 0$ & $19 / \pi$ & تعداد عروق خونى يرده كوريوآلانتوئيك جنين جوجه & \\
\hline$* \mathrm{P}<\cdot / \cdot \Delta$ & $\cdot / V$ & 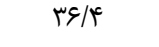 & 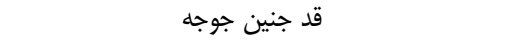 & \\
\hline 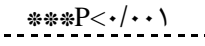 & $\therefore / 1 Y$ & $4 / 19$ & _ _ _ _ _ _ _ _ _ _ _ _ _ _ _ _ _ _ _ _ _ _ _ _ _ _ _ _ _ & \\
\hline$* * * \mathrm{P}<\cdot / \cdot+1$ & $1 / 9$ & $r \mu / D$ & طول عروق خونى يرده كوريوآلانتوئيك جنين جوجه & \multirow{4}{*}{ 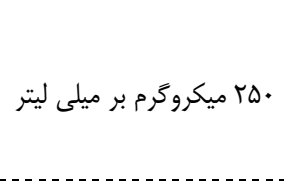 } \\
\hline$* * * * P<\cdot / \cdot+1$ & $1 / \infty$ & $\mid r / 9$ & تعداد عروق خونى يرده كوريوآلانتوئيك جنين جوجه & \\
\hline$* \mathrm{P}<\cdot / \cdot \Delta$ & $1 / 8$ & $r \Delta / l$ & ق قد جنين جوجه & \\
\hline$* * * * P<\cdot 1,+1$ & $\therefore 19$ & $\underline{m} 1 \cdot 1$ & 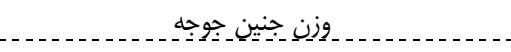 & \\
\hline$* * * * P<\cdot / \cdot+1$ & $1 / V$ & tr & طول عروق خونى يرده كوريوآلانتوئيك جنين جوجه & \multirow{4}{*}{ له ميكروگرم بر ميلى ليتر } \\
\hline$* * * * P<\cdot / \cdot+1$ & 1 & 11 & تعداد عروق خونى يرده كوريوآلانتوئيك جنين جوجه & \\
\hline$* \mathrm{P}<\cdot / \cdot \Delta$ & $\cdot / 4$ & $r \Delta / r$ & 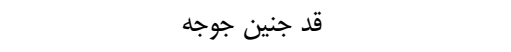 & \\
\hline 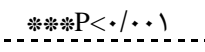 & $\therefore 110$ & r/M & 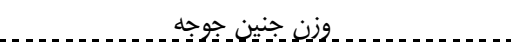 & \\
\hline$* * * \mathrm{P}<\cdot / \cdot \cdot 1$ & $r / \mu$ & $\mid N / r$ & طول عروق خونى يرده كوريوآلانتوئيك جنين جوجه & \multirow{4}{*}{ •... ميكروگرم بر ميلى ليتر } \\
\hline$* * * \mathrm{P}<\cdot / \cdot+1$ & 1 & $V / 9$ & تعداد عروق خونى يرده كوريوآلانتوئيك جنين جوجه & \\
\hline$* * * \mathrm{P}<\cdot / \cdot \bullet 1$ & $1 / r$ & $r F / l$ & ق قد جنين جوجه & \\
\hline$* * * * \mathrm{P}<\cdot / \cdot+1$ &.$/ 1 f$ & $r / I r$ & وزن جنين جوجه & \\
\hline
\end{tabular}



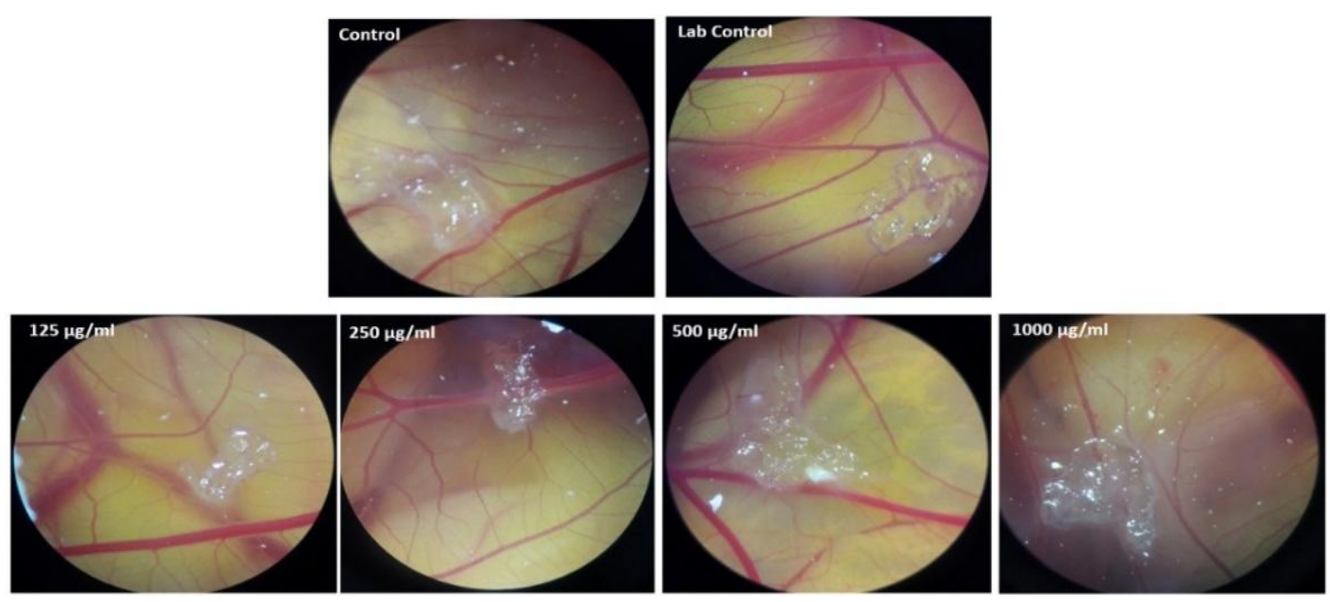

شكل ا - كاهش آنزيوزنز در سلولهاى تحت درمان با غلظتهاى مختلف نانوذرّات اكسيدروى سنتز شده با عصاره آبى تياه

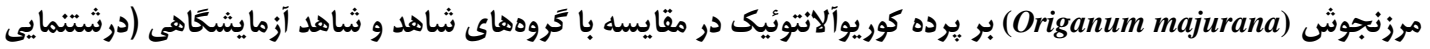

(i).

اولويتهاى درمانى هستند. يكى از عرصههاى بيشتاز در اين

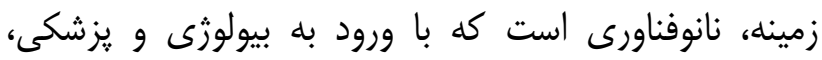
دستاوردهاى قابل توجهى در جهت مبارزه با سرطان داشته

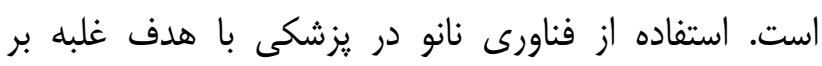
بيمارىهاى مختلف و سرطان در مقياس نانو، توجه محققان

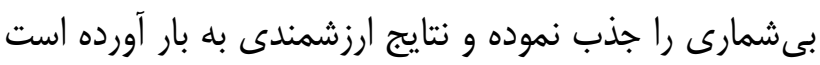

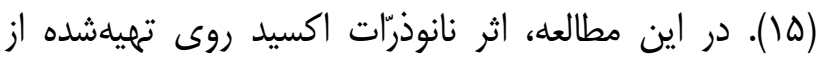

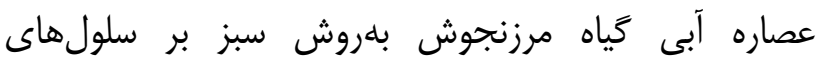

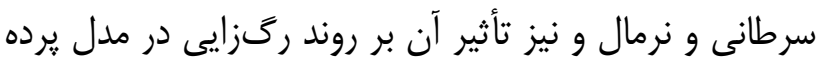

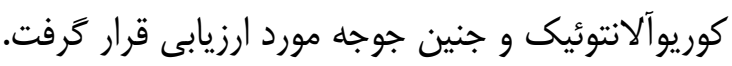

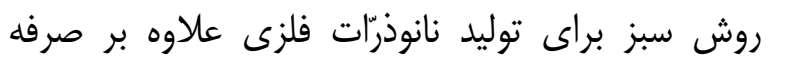

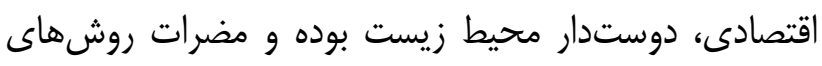

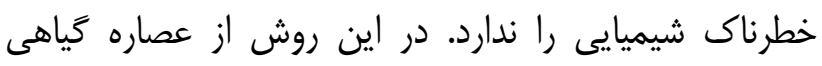

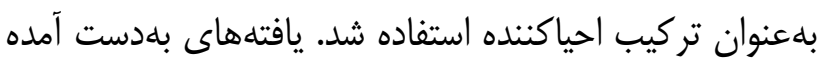

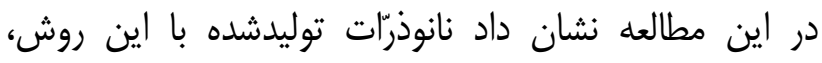
قدرت سايتوتوكسيك بيشترى بر سلولهاى سرطانى دانى ردهان Mep-G2 نرمال HUVEC دارند. همجنين نانوذرّات بيانشده قادرند

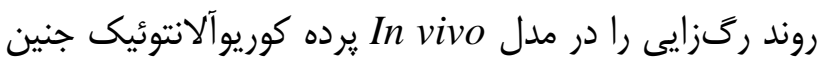

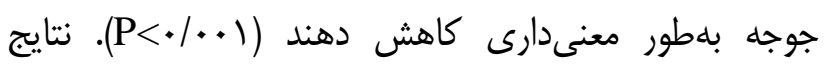

\section{بررسى ريختشناسى عروق خونى بعد از تيمار با}

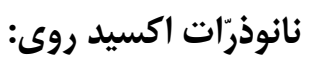
بررسى تغييرات ريختشناسى ميزان رتزايى بر يرده

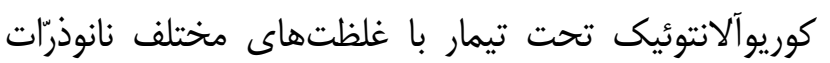

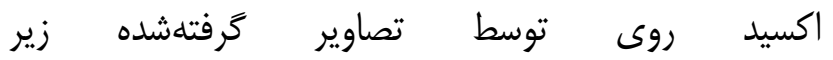
فتواسترئوميكروسكوٍ نشان داد كه افزايش غلظت نانوذرّرّات

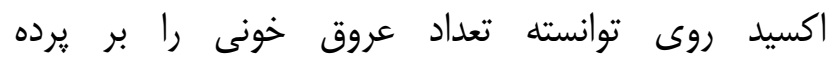
كوريوآلانتوئيك كاهش دهد (شكل (1). ييشخيرى از سرطان يكى از مهمترين استراتزىهاى

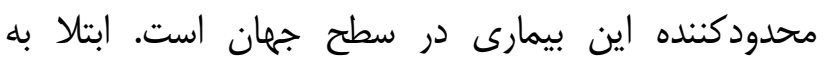

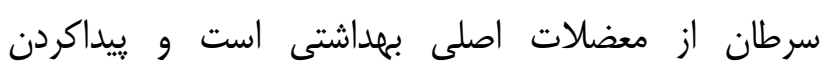

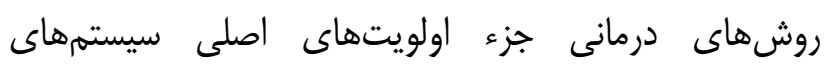

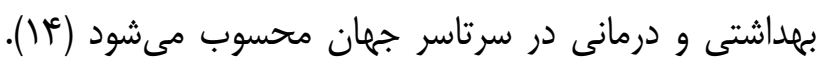

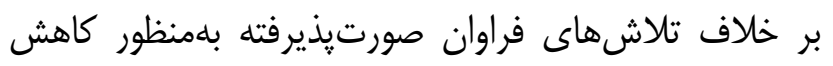
مبتلايان به سرطان، اين بيمارى در سالهاى اخير كسترش

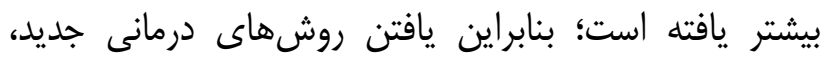

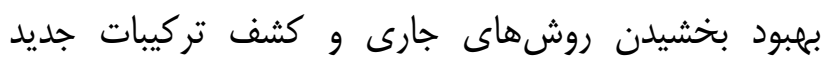

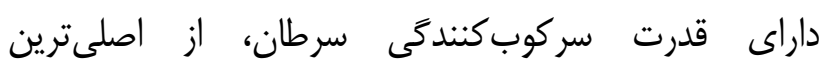


شد نانوذرّات توليدشده با روش سبز مىتوانند اثرات ضدّ

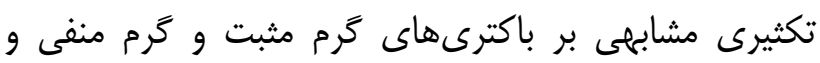
قارجها ايجاد كنند (19). بر اساس يافتههاى مطالعات اشارهشده و نتايج بلهدست

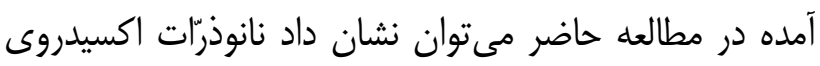

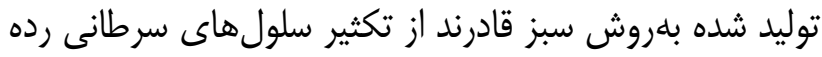

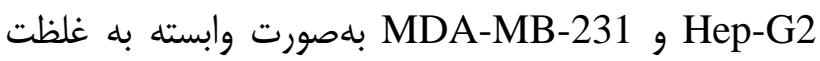
ممانعت نمايند. يكى از مهمترين مكانيسمهاى ييشنهادادشاه

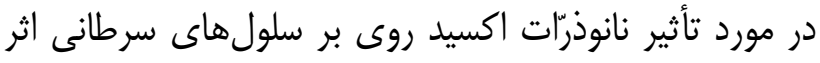
آيويتوتيك نانوذرّات بر اين سلولهاست (آل، • با). عوامل

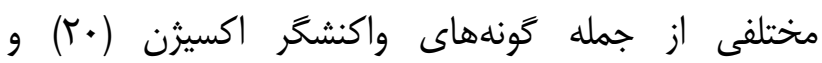

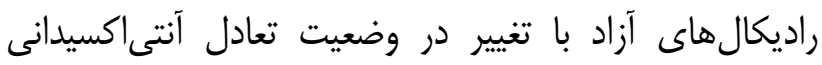

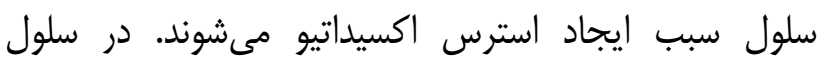

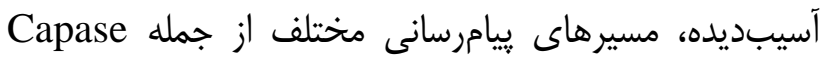

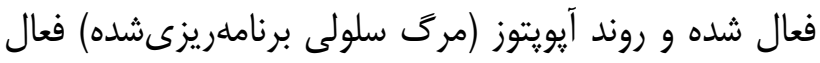

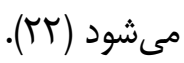
يكى از مهمترين عوامل در كسترش توده سرطانى،

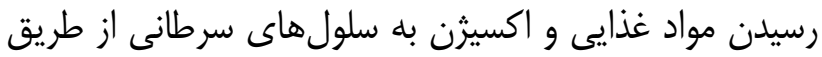

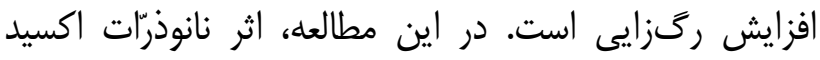

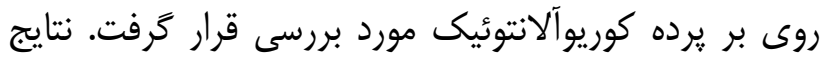
بهدست آمده از مطالعات مختلف نشان دادئ دادئد نانوذرّات اكسيد

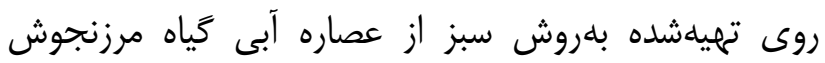
(Origanum majorana)

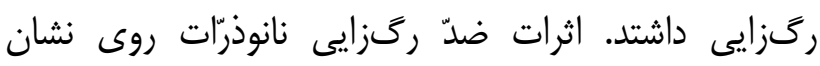

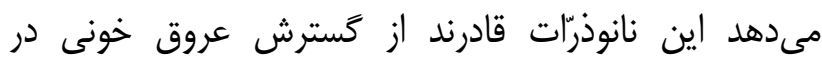

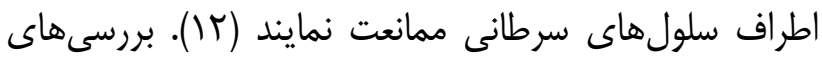

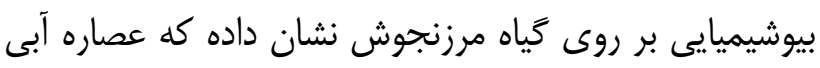

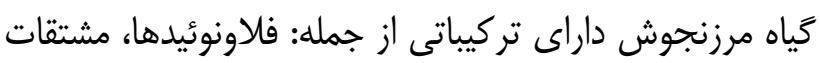

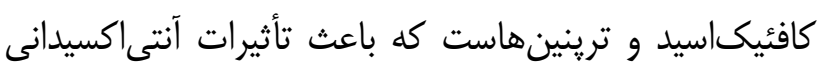

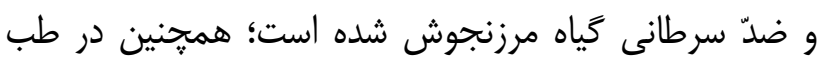

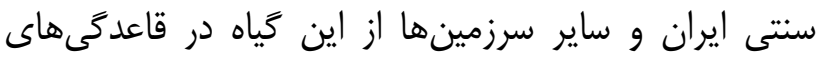
دردناك، آرتريت روماتوئيد، اختلالات دستخاه ادرارى، اسهال
مطالعه حاضر نشان داد نانوذرّات اكسيد روى قادرند بهصورت

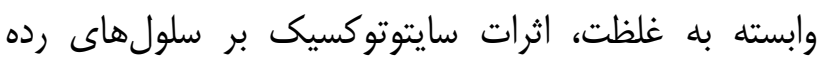
Hep-G2

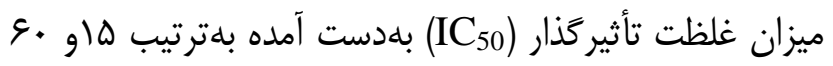

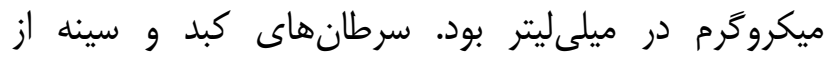
خطرناكترين سرطانهاى تهديدكننده سلامتى انسان هستند و به بافتهاى اصلى بدن حمله مى كنند. فناورى نانو در

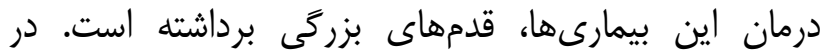

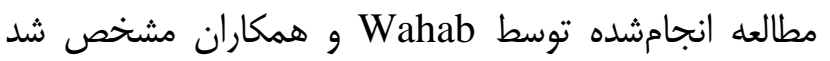

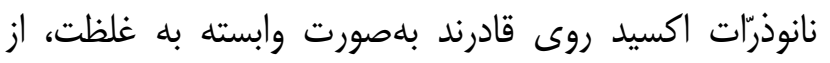

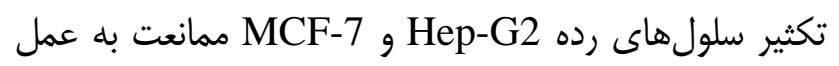

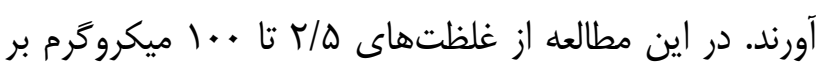

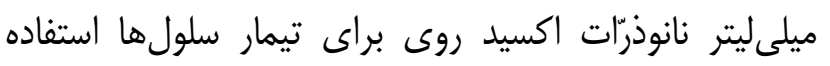

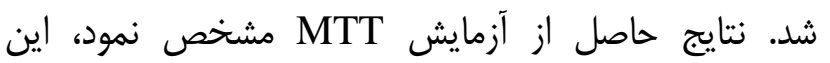

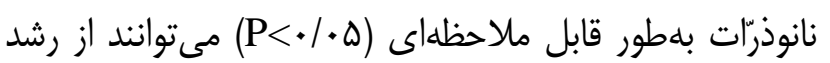
و تكثير سلول هاى فوق ممانعت نمايند (1).

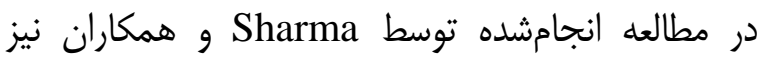

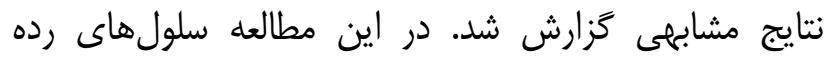

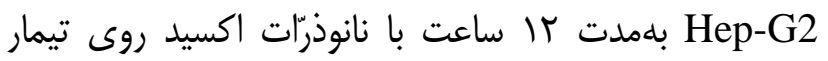

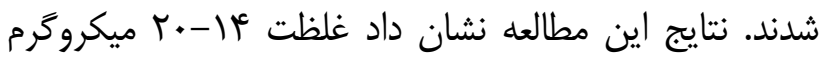

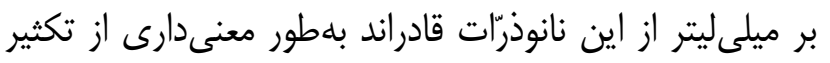

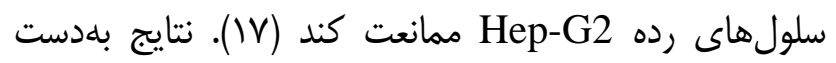

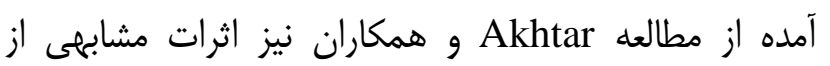

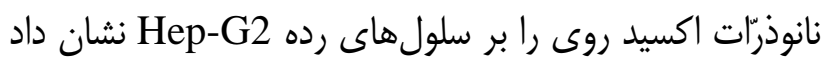

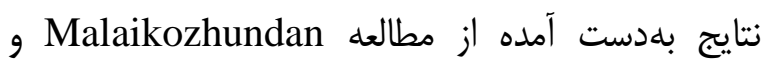
همكاران نشان داد سنتز نانوذرّات اكسيد روى با باستيات استفاده از

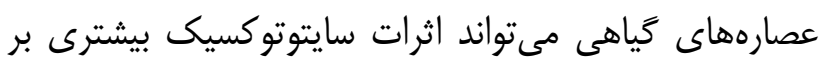

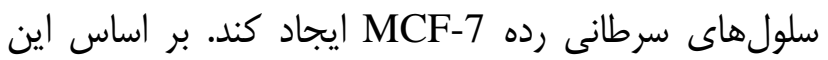

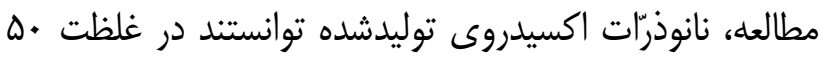

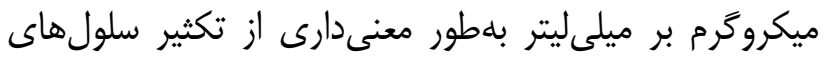
MCF-7 
نانوذرّات اكسيد روى تهيdشده به روش سبز از عصاره آبى

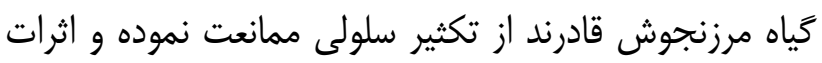
ضدّ رگزايى ايجاد نمايند.

\section{نتيجه كيرى}

به طور كلى مىتوان نتيجه گرفت كه غلظتهاى

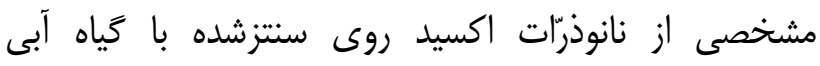
مرزنجوش (Origanum majorana)، باعث كاهش تعداد عروق خونى در ناحيه تيمارشده روى يرده كوريوآلانتوئيك

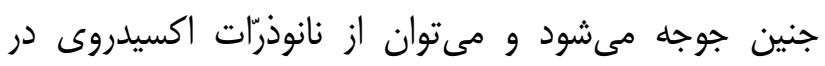

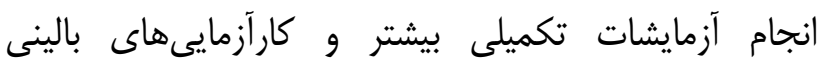

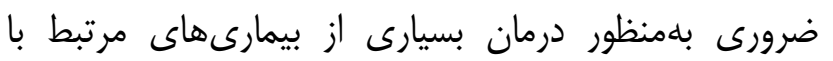

$$
\text { رگزايى استفاده كرد. }
$$

\section{تقدير و تشكر}

محققين لازم مىدانند مراتب تشكر خود را از مسئولين و

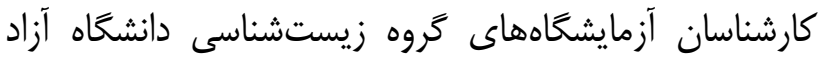

$$
\text { اسلامى مشهر ابراز دارند. }
$$

تعارض منافع

هيج گونه تعارض منافعى بين نويسندكان و عوامل دخيل در اين مطالعه اعلام نشده است. تعارصن مناقين

و استفراغ، تب و يرقان، اختلالات تنفسى از جمله سرفه و

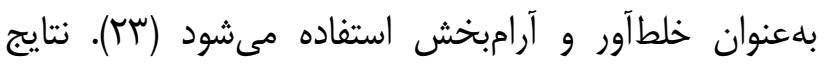
حاصل از اين مطالعه نشان مىدهد، استفاده از رقّتهاى كمتر

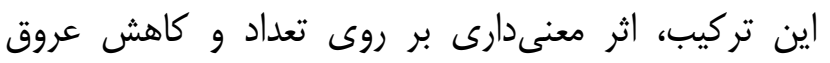

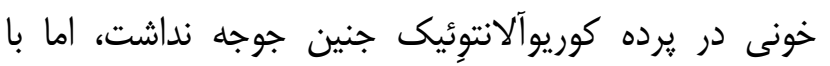

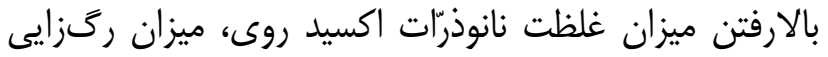

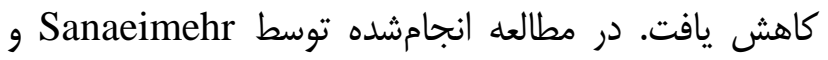

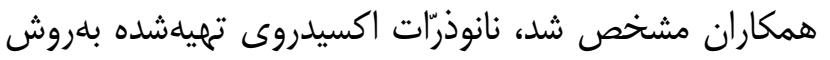

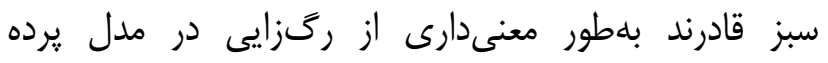

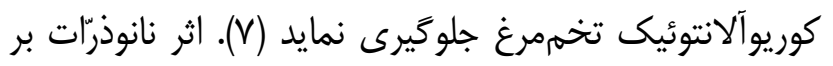

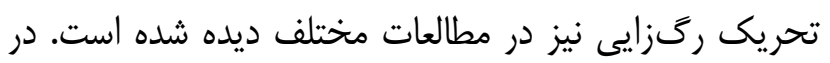

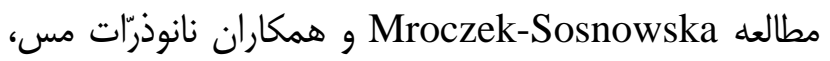
اثرات تحريك كنندگى رگزايى بر مدل يرده كوريوآلانتوئيى

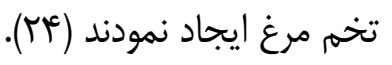
بلهور كلى نتايج در خصوص اثر نانوذرّات بر القاى رگزايى يا مهار اين فرايند بحثبرانخيز است. در مطالعه

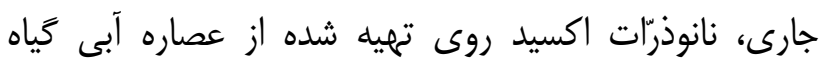

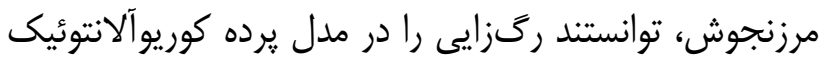

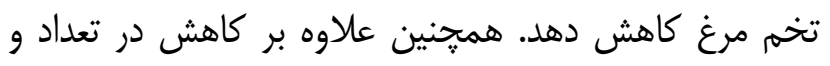

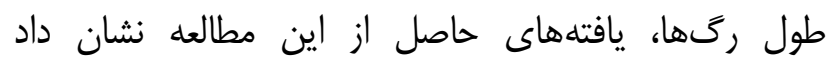

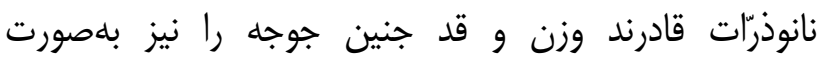
معنىدارى كاهش دهند. بر اساس يافتههاى مطالعه حاضر، جنورن

\section{منابع:}

1- Moloney JN, Cotter TG, editors. ROS signalling in the biology of cancer. Seminars in cell \& developmental biology; 2018: Elsevier.

1- Moloney JN, Cotter TG. ROS signalling in the biology of cancer. Semin Cell Dev Biol. 2018; 80: 50-64. doi: 10.1016/j.semcdb.2017.05.023.

2- Pasculli B, Barbano R, Parrella P. Epigenetics of breast cancer: Biology and clinical implication in the era of precision medicine. Semin Cancer Biol. 2018; 51: 22-35. doi: 10.1016/j.semcancer.2018.01.007.

3- Rogers MS, D'amato RJ. The effect of genetic diversity on angiogenesis. Exp Cell Res. 2006; 312(5): 561-74. DOI: 10.1016/j.yexcr.2005.10.021

4- Tambe P, Kumar P, Paknikar KM, Gajbhiye V. Decapeptide functionalized targeted mesoporous silica nanoparticles with doxorubicin exhibit enhanced apoptotic effect in breast and prostate cancer cells. Int $\mathrm{J}$ Nanomedicine. 2018;13:7669-80. doi: 10.2147/IJN.S184634 
5- Divya M, Vaseeharan B, Abinaya M, Vijayakumar S, Govindarajan M, Alharbi NS, et al. Biopolymer gelatin-coated zinc oxide nanoparticles showed high antibacterial, antibiofilm and anti-angiogenic activity. J Photochem Photobiol B. 2018; 178: 211-8. doi: 10.1016/j.jphotobiol.2017.11.008.

6- Ali A, Ahmed S. A review on chitosan and its nanocomposites in drug delivery. International journal of biological macromolecules. 2018; 109: 273-86. doi: 10.1016/j.ijbiomac.2017.12.078

7- Sanaeimehr Z, Javadi I, Namvar F. Antiangiogenic and antiapoptotic effects of green-synthesized zinc oxide nanoparticles using Sargassum muticum algae extraction. Cancer Nanotechnol. 2018; 9(1): 3. doi: 10.1186/s12645-018$0037-5$.

8- Ancona A, Dumontel B, Garino N, Demarco B, Chatzitheodoridou D, Fazzini W, et al. Lipid-coated zinc oxide nanoparticles as innovative ROS-generators for photodynamic therapy in cancer cells. Nanomaterials (Basel). 2018; 8(3): pii: E143. doi: 10.3390/nano8030143.

9- Attoub S, Shahrazad S, Kholoud A. PO-419 Use of origanum majorana oil in lung cancer therapy. ESMO Open 2018; 3(Suppl 2): A187. doi: 10.1136/esmoopen-2018-EACR25.445

10- Skehan P, Storeng R, Scudiero D, Monks A, McMahon J, Vistica D, et al. New colorimetric cytotoxicity assay for anticancer-drug screening. J Natl Cancer Inst. 1990; 82(13): 1107-12. DOI: 10.1093/jnci/82.13.1107

11- Nair S, Sasidharan A, Divya Rani VV, Menon D, Nair S, Manzoor K, et al. Role of size scale of ZnO nanoparticles and microparticles on toxicity toward bacteria and osteoblast cancer cells. J Mater Sci Mater Med. 2009; 20 Suppl 1: S235-41. doi: 10.1007/s10856-008-3548-5.

12- Safavi E, Homayounitabrizi M, Karimi E. Investigation of Antiangiogenic Properties of Green ZnO Nanoparticles Synthesized By Root Extract of Persicaria bistorta. Sci J Ilam Univ Med Sci. 2018; 26(2): 45-56. [Persian]

13- Ghandehari S, Homayouni Tabrizi M, Ardalan P. Evaluation of Anti-angiogenic Activity of Silver Nanoparticle Synthesis by Rubina tinctorum L (Ru-AgNPs) Using Chicken Chorioallantoic Membrane (CAM) Assay. Arak Med Univ J. 2018; 21(1): 82-90. [Persian]

14- Odisho AY, Rabban JT, Meng MV. Development of CNS-type primitive neuroectodermal tumor in metastatic testicular mixed germ cell tumor. Urol Case Rep. 2016; 6: 7-8. doi: 10.1016/j.eucr.2016.01.003

15- Kalepu S, Nekkanti V. Improved delivery of poorly soluble compounds using nanoparticle technology: a review. Drug Deliv Transl Res. 2016; 6(3): 319-32. doi: 10.1007/s13346-016-0283-1.

16- Wahab R, Siddiqui MA, Saquib Q, Dwivedi S, Ahmad J, Musarrat J, et al. ZnO nanoparticles induced oxidative stress and apoptosis in HepG2 and MCF-7 cancer cells and their antibacterial activity. Colloids Surf B Biointerfaces. 2014; 117: 267-76. doi:10.1016/j.colsurfb.2014.02.038

17- Sharma V, Anderson D, Dhawan A. Zinc oxide nanoparticles induce oxidative DNA damage and ROS-triggered mitochondria mediated apoptosis in human liver cells (HepG2). Apoptosis. 2012;17(8): 852-70. doi: 10.1007/s10495012-0705-6.

18- Akhtar MJ, Ahamed M, Kumar S, Khan MM, Ahmad J, Alrokayan SA. Zinc oxide nanoparticles selectively induce apoptosis in human cancer cells through reactive oxygen species. Int J Nanomedicine. 2012; 7: 845-57. doi: 10.2147/IJN.S29129.

19- Malaikozhundan B, Vaseeharan B, Vijayakumar S, Pandiselvi K, Kalanjiam MAR, Murugan K, et al. Biological therapeutics of Pongamia pinnata coated zinc oxide nanoparticles against clinically important pathogenic bacteria, fungi and MCF-7 breast cancer cells. Microb Pathog. 2017; 104: 268-77. doi: 10.1016/j.micpath.2017.01.029.

20- Namvar F, Rahman HS, Mohamad R, Azizi S, Tahir PM, Chartrand MS, et al. Cytotoxic effects of biosynthesized zinc oxide nanoparticles on murine cell lines. Evid Based Complement Alternat Med. 2015; 2015: 593014. doi: $10.1155 / 2015 / 593014$.

21- Liu T, Liang H, Liu L, Gong Y, Ding Y, Liao G, et al. Influence of pristine and hydrophobic ZnO nanoparticles on cytotoxicity and endoplasmic reticulum (ER) stress-autophagy-apoptosis gene expression in A549-macrophage coculture. Ecotoxicol Environ Saf. 2019; 167: 188-95. doi: 10.1016/j.ecoenv.2018.10.018. 
22- Simon HU, Haj-Yehia A, Levi-Schaffer F. Role of reactive oxygen species (ROS) in apoptosis induction. Apoptosis. 2000; 5(5): 415-8. DOI: 10.1023/a:1009616228304

23- Al Dhaheri Y, Attoub S, Arafat K, AbuQamar S, Viallet J, Saleh A, et al. Anti-metastatic and anti-tumor growth effects of Origanum majorana on highly metastatic human breast cancer cells: inhibition of NFKB signaling and reduction of nitric oxide production. PLoS One. 2013; 8(7): e68808. doi: 10.1371/journal.pone.0068808.

24- Mroczek-Sosnowska N, Sawosz E, Vadalasetty KP, Łukasiewicz M, Niemiec J, Wierzbicki M, et al. Nanoparticles of copper stimulate angiogenesis at systemic and molecular level. Int J Mol Sci. 2015; 16(3): 4838-49. doi: 10.3390/ijms 16034838. 